\title{
EKSTRAKSI LEMAK SEL TUNGGAL MIKROBA YANG BERPOTENSI MENGHASILKAN BIODIESEL
}

\author{
Single Cells Fat Extraction Potential to Produce Biodiesel
}

\author{
Joko Sulistyo dan Sri Purwaningsih \\ Pusat Penelitian Biologi, Lembaga IImu Pengetahuan Indonesia \\ Cibinong Science Center \\ Jl. Raya Bogor - Jakarta Km. 46 Cibinong 16911 \\ E-mail: josulisty@yahoo.com
}

Diterima: 06 Juli 2013; Dikoreksi: 30 Juli 2013; Disetujui: 21 Agustus 2013

\begin{abstract}
Some microbial and microalgal strains are able to accumulate fatty acid in their cells, making them potential sources of single cell lipid production. Biodiesel from single cell lipid can be obtained by modifying fatty acids through esterification and transesterification processes using methanol in the presence of strong base or acid catalysts. The purpose of this study was to investigate the potential of bacterial and algal strains to produce biodiesel from single cell lipid by conducting a series of extraction procedure including incubation, oil extraction, esterification and indirect trans-esterification. Transesterification using hexane-isopropanol solvent produces a high fatty acid methyl esters content. Single cell lipids extracted from molds (Monascus purpureus, Monilia sitophyla, Aspergillus oryzae, Mucor javanicus, Fusarium oxysporum) and algae (Chlorella vulgaris and Scenedesmus dimorphus) can be converted to biodiesel by indirect transesterification at high temperature using high amount of anhydrous methanol and sodium hydroxide as catalyst. Single cell lipids derived from molds $F$. Oxysporum and $M$. Javanicus were predominated with palmitic acid (41\% and $40 \%)$, while those were of mold of A. Oryzae, M. Purpureus and M. Sitophyla were predominated with linoleic acid 42 $\%, 36,1 \%$ and $36 \%)$. Single cell lipids of algae $C$. Vulgaris was predominated with linolenic acid (47 $\%)$, while those were of algal S. Limorphus was predominated with linoleic acid (35\%). Palmitic and linoleic acids can be modified through esterification to make biodiesel. In transesterification, a large amount of methanol was used to produce more methyl esters as a final product.
\end{abstract}

Keywords: algae, single cell lipid, esterification, transesterification

\begin{abstract}
Abstrak
Beberapa biakan mikroba dan mikroalga dapat menghasilkan biomasa yang mengandung asam lemak, sehingga berpotensi sebagai sumber penghasil lemak sel tunggal. Pembuatan biodiesel dari lemak sel tunggal dapat diproduksi dengan memodifikasi asam lemak melalui esterifikasi dan transesterifikasi menggunakan metanol serta basa atau asam kuat sebagai katalis. Tujuan dari penelitian adalah untuk mengeksplorasi potensi biakan mikroba dan alga sebagai penghasil lemak sel tunggal mulai dari penyiapan bahan, inkubasi, ekstraksi minyak, esterifikasi dan transesterifikasi biomasa secara tidak langsung. Transesterifikasi dengan pelarut heksan-isopropanol akan menghasilkan kandungan metil ester asam lemak yang tinggi. Lemak sel tunggal yang diekstraksi dari biakan kapang (Monascus purpureus, Monilia sitophyla, Aspergillus oryzae, Mucor javanicus, Fusarium oxysporum) dan alga (Chlorella vulgaris and Scenedesmus dimorphus) dapat menghasilkan biodiesel melalui transesterifikasi secara langsung, menggunakan panas setelah penambahan sejumlah banyak metanol anhidrat dan sodium hidroksida sebagai katalis yang berperan untuk meningkatkan kecepatan reaksi serta hasil yang diperoleh. Lemak sel tunggal pada kapang $F$. Oxysporum dan M. Javanicus didominasi oleh asam palmitat (41\% dan $40 \%$ ), sedangkan pada kapang A. Oryzae, M. Purpureus dan M. Sitophyla didominasi oleh asam linoleat (42 \%, 36,1 \% dan $36 \%$ ). Sedangkan pada alga $C$. Vulgaris didominasi oleh asam linolenat $(47 \%)$, dan pada alga S. Limorphus didominasi oleh asam linoleat (35\%). Asam palmitat dan linoleat berpotensi untuk menghasilkan biodiesel melalui esterifikasi. Dimana, sejumlah banyak metanol digunakan untuk menghasilkan lebih banyak metil ester sebagai produk akhir.
\end{abstract}

Kata kunci: alga, lemak sel tunggal, esterifikasi, transesterifikasi 


\section{PENDAHULUAN}

Melambungnya harga bahan bakar minyak dan semakin menipisnya cadangan minyak bumi, telah memacu eksplorasi sumberdaya lain penghasil energi termasuk potensi dari sumberdaya mikroba, yang dapat digunakan sebagai sumber energi alternatif, antara lain alga, khamir dan kapang. Bahan bakar alternatif yang dapat digunakan sebagai pengganti bahan bakar minyak fosil, antara lain adalah bioetanol dan biodiesel [1].

Menurut Aaronson (1980) [2], alga hijau memiliki kandungan total lemak $16-60 \%$ dari berat kering, namun kapang dan khamir memiliki kandungan total lemak yang relatif lebih rendah dibandingkan alga.

Alga dapat dimanfaatkan sebagai sumber penghasil energi. Salah satu cara yang efisien adalah penggunaan lemak alga untuk menghasilkan biodiesel. Beberapa alga dapat memproduksi gas hidrogen di bawah kondisi pertumbuhan yang khusus. Biomassa dari alga juga dapat dibakar seperti kayu untuk menghasilkan panas dan aliran listrik[3].

Biodiesel adalah merupakan monoalkil ester dari asam-asam lemak rantai panjang yang terkandung dalam minyak nabati atau lemak hewani untuk digunakan sebagai bahan bakar mesin diesel. Biodiesel dapat diperoleh melalui reaksi transesterikasi atau esterifikasi asam lemak bebas dari trigliserida[4].

Esterifikasi adalah tahap konversi dari asam lemak bebas menjadi ester. Esterifikasi mereaksikan minyak lemak dengan alkohol. Katalis yang digunakan dalam reaksi ini adalah asam kuat seperti asam sulfat[5]. Esterifikasi biasa dilakukan untuk membuat biodiesel dari minyak berkadar asam lemak bebas tinggi[6].

Biodiesel tidak menimbulkan efek negatif terhadap kesehatan dibanding bahan bakar fosil, karena berasal dari bahan organik sehingga tidak menyebabkan pencemaran logam berat atau lingkungan.

Tujuan dari penelitian ini adalah untuk mengekstraksi lemak sel tunggal mikroba yang berpotensi dijadikan biodiesel melalui reaksi transesterifikasi.

\section{BAHAN DAN METODE}

\subsection{Bahan-Bahan yang Digunakan}

Biakan mikroba yang digunakan antara lain alga (Chlorella vulgaris. Scenedesmus limorphus), kapang (Monascus purpureus, Monilia sitophyla, Aspergillus oryzae, Mucor javanicus, Fusarium oxysporum). Bahan-bahan untuk pembuatan media pertumbuhan antara lain; glukosa, yeast extract, $\mathrm{KH}_{2} \mathrm{PO}_{4}, 3,5$-Dinitrosalicylic acid, PDA, buffer $\mathrm{pH} 6,5, \mathrm{Na}_{2} \mathrm{SO}_{4}, \mathrm{NaOH}$ dan $\mathrm{BF} 3$ dalam methanol, $\mathrm{NaCl}$, heksan isopropanol dan alkohol.

\subsection{Menumbuhkan Biakan Mikroba}

Biakan yang telah berumur 2-3 hari pada media PDA, diinokulasikan kedalam media cair mengandung $2 \%$ glukosa, 0,5\% yeast extract dan $0,1 \% \mathrm{KH}_{2} \mathrm{PO}_{4}$ pada $\mathrm{pH} 6,5$. Masing-masing biakan diinokulasikan dalam $100 \mathrm{~mL}$ media cair. Setelah diinokulasikan, biakan tersebut kemudian diinkubasikan di atas shaker pada suhu ruang dengan kecepatan 150 rpm selama 4-5 hari.

\subsection{Produksi Lemak Sel Tunggal}

Biakan yang telah berumur 4-5 hari kemudian disaring dengan kertas saring Whatman No. 1 guna memisahkan biomassa dan cairan. Biomassa dikeringbekukan pada $-40^{\circ} \mathrm{C}$ dan 0,15 Mbar hingga diperoleh berat konstan. Cairan tanpa biomassa selanjutnya digunakan untuk penentuan COD dan kadar gula reduksi. COD ditentukan berdasarkan metode APHA dan penentuan gula reduksi berdasarkan metode DNS.

Ekstraksi Lemak Sel Tunggal (LST) berdasarkan metode Lepage yang dimodifikasi. Larutan heksan-isopropanol sebanyak $10 \mathrm{~mL}$ (3:2, $\mathrm{v} / \mathrm{v}$ ) ditambahkan pada biomassa yang sudah dikeringbeku dalam tabung sentrifugal $45 \mathrm{~mL}$, dihomogenasi selama 1 menit dan disentrifus pada 5000 rpm selama 10 menit. Prosedur ekstraksi diulang sebanyak 2 kali pada residunya dan ketiga supernatan yang telah diperoleh digabung kembali. Sebanyak $10 \mathrm{~mL}$ sodium sulfat $0,47 \mathrm{M}$ kemudian ditambakan pada supernatan untuk memecah emulsi. Fasa teratas yang mengandung LST kemudian dipindahkan pada tabung lainnya dan dievaporasi hingga kering menggunakan gas nitrogen di atas penangas air pada suhu $45^{\circ} \mathrm{C}$. Berat kering residu ditentukan sebagai berat total LST.

\subsection{Esterifikasi Lemak Sel Tunggal}

Lemak berbentuk minyak sebanyak 0,5 $\mathrm{mL}$ dimasukkan ke dalam tabung reaksi dan kemudian ditambah $15 \mathrm{~mL} 0,5 \mathrm{M} \mathrm{NaOH}$ dalam metanol. Tabung ditutup rapat lalu divortex, dipanaskan selama 5 menit pada suhu $80^{\circ} \mathrm{C}$, kemudian didinginkan dan ditambah $10 \mathrm{~mL} \mathrm{BF3}$ dalam metanol $30 \%$ kemudian divotex. Larutan dipanaskan kembali pada suhu $85^{\circ} \mathrm{C}$ selama 30 menit, didinginkan dan ditambah $5 \mathrm{~mL}$ hexan dan $15 \mathrm{~mL} \mathrm{NaCl}$ jenuh. Setelah divortex, lapisan hexan dipipet kemudian ditambahkan ke dalam $5 \mathrm{gr}$ $\mathrm{Na}_{2} \mathrm{SO}_{4}$ unhydrat. Hasil yang diperoleh dianalisis menggunakan GC.

\section{HASIL DAN PEMBAHASAN}

\subsection{Ekstraksi LST dari Biakan Kapang}

Gambar 1 menunjukkan pertumbuhan biakan 
kapang M. Purpureus, M. Sitophyla, M. Javanicus, $F$. Oxysporum dan $A$. Oryzae pada medium PDA berumur 2-3 hari. Biakan Monascus yang ditumbuhkan pada medium toge agar tumbuh paling lambat diantara biakan kapang yang lain, sedangkan biakan kapang yang lain ditumbuhkan pada medium PDA. Semua biakan kapang menunjukkan pertumbuhan yang optimal pada umur 2-3 hari, sehingga dapat diinokulasikan ke media cair, namun $M$. sitophyla tumbuh paling cepat dibandingkan kapang yang lainnya. Kapang ini lebih cepat membentuk propagul sehingga dalam inokulasi harus ekstra hati-hati sebab dapat mengkontaminasi biakan yang lain.

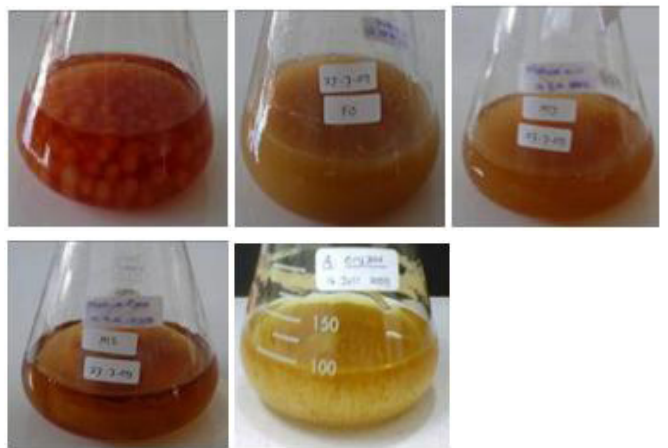

Gambar 1. Biakan kapang M. purpureus (A), F. oxysporum (B), M. javanicus (C), M. sitophyla (D), A. oryzae (C, ditumbuhkan dalam media cair.

\subsection{Ekstraksi Lemak Sel Tunggal}

Biakan yang telah diinkubasi dengan cara digoyang diatas shaker selama 4-5 hari, siap untuk dipanen dan dilakukan proses ekstraksi LST. Biakan M. purpureus dalam medium cair tumbuh dengan baik dan relatif lebih cepat. Media biakan berwarna merah dan koloninya miselianya membentuk pellet berbentuk bulat dengan ukuran yang relatif besar dibanding kapang yang lain. Biakan yang tumbuh cepat menyebabkan media cair menjadi sangat kental dan berwarna coklat keruh. Namun, vikositas dari media cair ini lebih rendah dibanding viskositas pada media yang ditumbuhi kapang F. Oxysporum.

Media cair menjadi berwarna agak kemerahan dan terdapat koloni jamur yang berwarna putih kekuningan. Koloni jamur berwarna putih dan berbentuk bulat. Kapang tumbuh dengan baik dan sangat subur. Setiap biakan kapang memiliki kecepatan dan performa tumbuh yang berbeda -beda. Perbedaan struktur dapat memungkinkan perbedaan kandungan LSTnya.

Untuk tujuan perbanyakan sel, $5 \mathrm{~mL}$ biakan cair diinokulasikan ke dalam $45 \mathrm{~mL}$ media segar, kemudian dihomogenasi untuk menghancurkan koloni kapang sehingga menjadi sel-sel tunggal yang homogen. Sel-sel tersebut selanjutnya diekstraksi lemaknya sehingga diperoleh LST.
Biakan yang telah homogen kemudian disaring menggunakan kertas Whatman No. 1. Biakan A. oryzae tidak perlu dihomogenkan namun langsung disaring menggunakan kertas saring biasa, karena biakan $A$. oryzae memiliki ukuran spora yang besar sehingga dapat disaring secara langsung. Biakan M. purpureus, M. sitophyla, $M$. javanicus, F. oxysporum dihomogenkan kemudian disentrifus dengan kecepatan 10.000 rpm selama 10 menit sehingga diperoleh supernatan dan presipitan (pelet)
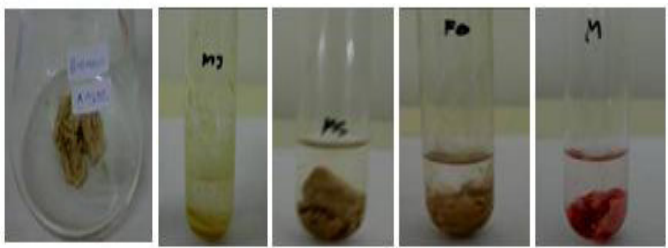

Gambar 2. Pelet dan supernatan dari biakan $A$. oryzae, M. javanicus, M. sitophyla, F. oxysporum, dan M. purpureus.

Biomassa yang diperoleh kemudian dikeringbekukan menggunakan freeze dryer sehingga diperoleh biomassa kering dengan berat konstan. Tujuan penggunaan freeze dryer adalah untuk menghilangkan residu air yang terkandung dalam biomassa sehingga diperoleh biomassa kering. Supernatan tanpa biomassa selanjutnya digunakan untuk penentuan kadar gula pereduksi berdasarkan metode DNS. Kandungan gula pereduksi tertinggi ditunjukkan pada media biakan F. oxysporum (11,903ppm) (Tabel 1).

Tabel 1. Kadar gula reduksi pada masing-masing biakan kapang.

\begin{tabular}{lcc}
\hline Biakan & Absorbansi & $\begin{array}{c}\text { Kadar Gula } \\
\text { Reduksi } \\
\text { (ppm) }\end{array}$ \\
\hline A. oryzae & 0,6215 & 6,473 \\
M. purpureus & 0,0563 & \\
F. oxysporum & 0,4934 & 4,732 \\
M. sitophyla & 0,0343 & 1,1575 \\
M. javanicus & 0,1113 & \\
& 0,3486 & 3,143 \\
& 0,017 & 2,679 \\
\hline
\end{tabular}

Guna mengekstraksi lemak yang terkandung dalam biomasa, masing-masing biomassa yang diperoleh dari biakan kapang kemudian dikeringkan dan ditambah larutan heksan -isopropanol (3:2, v/v). Campuran kemudian dihomogenasi selama 10-20 menit kemudian disentrifus pada 10.000 rpm selama 10 menit. Perlakuan diulang sebanyak dua kali. Supernatan yang diperoleh kemudian digabung kembali dan 
ditambah larutan sodium sulfat 0,47M. Hasil ekstraksi lemak, sebagaimana ditunjukkan pada Tabel 2. Supernatan yang diperoleh kemudian dievaporasi pada suhu $60^{\circ} \mathrm{C}$. Suhu ini merupakan titik didihnya heksan sehingga lerutan heksan akan menguap dan LST akan tetap berada di labu evaporator. Proses evaporasi dihentikan ketika supernatan yang tersisa tinggal $\pm 10 \mathrm{~mL}$. Hasil evaporasi ini kemudian dianalisis kadar dan jenis asam lemaknya menggunakan metode Gas Chromatography (GC), guna memisahkan senyawa berdasarkan tingkat polaritasnya.

\subsection{Esterifikasi}

Esterifikasi adalah poses pembentukan ester dari asam karboksilat dan alkohol, keduanya bergabung melepaskan sebuah molekul air dalam proses tersebut.

Proses esterifikasi ini merupakan tahapan akhir dalam pembuatan biodiesel. Minyak yang diperoleh dari ekstraksi lemak diesterifikasi hingga menjadi metil ester dan gliserol. Metil ester yang diperoleh dari proses esterifikasi tersebut merupakan biodiesel.

Biodiesel didefinisikan sebagai mono-alkil ester dari asam-asam lemak rantai panjang yang terkandung dalam minyak nabati atau lemak hewani untuk digunakan sebagai bahan bakar mesin diesel. Biodiesel dapat diperoleh melalui reaksi esterifikasi asam lemak bebas tergantung dari kualitas minyak nabati yang digunakan sebagai bahan baku [4].

Tabel 2. Hasil Analisis Lemak Sel Tunggal Ekstraksi Lemak Sel Tunggal Alga

\begin{tabular}{llccccc}
\hline No & Jenis Analisis & F. oxysporum & M. javanicus & Analisis (\%) & & \\
& & 0.0 & 0.0 & 0.0 & 0.0 & M. sitophyla \\
M. purpureus \\
\hline $\mathbf{1}$ & Laurat (C12-0) & 0.0 & 8.5 & 0.0 & 0.0 & 0.0 \\
$\mathbf{2}$ & Miristat (C14-0) & 41.0 & 40.0 & 20.0 & 16.1 & 18.0 \\
$\mathbf{3}$ & Palmitat (C16-0) & 14.0 & 11.1 & 16.1 & 5.0 & 7.0 \\
$\mathbf{4}$ & Stearat (C18-0) & 13.0 & 13.1 & 14.0 & 14.2 & 13.2 \\
$\mathbf{5}$ & Oleat (C18-1) & 20.2 & 20.2 & 42.0 & 36.0 & 36.1 \\
$\mathbf{6}$ & Linoleat (C18-2) & 10.2 & 6.0 & 6.0 & 16.1 & 16.4 \\
$\mathbf{7}$ & Linolenat (C18-3) & 1.2 & 2.0 & 1.2 & 1.0 & 1.9 \\
$\mathbf{8}$ & Arachidonat (C20-0) & 0.1 & 0.1 & 1.0 & 10.1 & 7.4 \\
$\mathbf{9}$ & Lain-lain & &
\end{tabular}

Biodiesel hasil penelitian dapat digunakan sebagai bahan bakar alternatif pengganti minyak diesel dari minyak bumi. Biodiesel juga dapat dimanfaatkan sebagai bahan bakar pada kompor biokerosin.

Alga yang digunakan dalam penelitian ini yaitu Chlorella vulgaris dan Scenedesmus limorphus. Biomassa alga yang diperoleh dalam bentuk basah kemudian dikering bekukan dengan freezedryer, sehingga didapatkan biomassa kering. Setelah itu, biomassa dari kedua alga ditambah larutan heksan-isopropanol sebanyak $50 \mathrm{~mL}$ dan didiamkan selama satu malam $( \pm 12$ jam), guna mengekstraksi LST alga, sehingga proses ekstraksi dapat berlangsung secara optimal. Campuran dihomogenkan selama 10-20 menit, agar lemak yang berada di dalam alga dapat keluar sehingga proses ekstraksi lemak berjalan sempurna. Campuran setelah dihomogenasi kemudian disentrifus pada kecepatan $10.000 \mathrm{rpm}$ sekama 10 menit. Perlakuan diulang sebanyak dua kali.

Ketiga supernatan yang diperoleh digabung kembali dan ditambah dengan $10 \mathrm{~mL}$ sodium sulfat 0,47 M., Selanjutnya dilakukan evaporasi dengan suhu $60{ }^{\circ} \mathrm{C}$. Suhu ini merupakan titik didihnya heksan sehingga lerutan heksan akan menguap dan lemak sel tunggal akan tetap di labu evaporator. Evaporasi dihentikan sampai supernatant tersisa $\pm 10 \mathrm{~mL}$. Kemudian hasil dari evaporasi tersebut dianalisis sehingga dapat diketahui kadar dan jenis lemak dari masing -masing jenis alga, sebagaimana ditunjukkan pada Tabel 3.

Tabel 3. Kandungan lemak sel tunggal alga.

\begin{tabular}{|c|c|c|}
\hline \multirow[t]{2}{*}{ Jenis Analisis } & \multicolumn{2}{|c|}{ Hasil Analisis } \\
\hline & CV & SL \\
\hline Laurat (C12-0) & 0.0 & 0.3 \\
\hline Miristat (C14-0) & 0.0 & 0.0 \\
\hline Palmitat (C16-0) & 14.0 & 17.0 \\
\hline Stearat (C18-0) & 6.9 & 7.0 \\
\hline Oleat (C18-1) & 4.7 & 16.0 \\
\hline Linoleat (C18-2) & 20.0 & 35.0 \\
\hline Linolenat (C18-3) & 47.0 & 10.2 \\
\hline Arachidonat (C20-0) & 6.0 & 2.3 \\
\hline Lain-lain & 0.8 & 10.1 \\
\hline
\end{tabular}

Keterangan ; CV, Chlorella vulgaris; SL, Scenedesmus limorphus

Metode yang digunakan untuk analisis kadar dan jenis lemak dengan metode Gas Chromatography (GC). Hasil dari analisis sebagaimana ditunjukkan pada Tabel 3. Lemak yang dihasilkan dari ekstraksii lemak pada $C$. vulgaris adalah 0,25 gram dengan berat kering $C$. vulgaris sebesar 2,507 gram, Total lemak pada $C$. vulgaris adalah sebesar 9,97\% dari berat kering.

Setelah diperoleh lemak sel tunggal, kemudian 
dilakukan esterifikasi dengan prosedur yang sama. Pada alga S. Limorphus total lemak yang diperoleh terlalu sedikit sehingga tidak dilakukan esterifikasi.

Metil ester yang diperoleh dari proses esterifikasi merupakan biodiesel. Namun, biodiesel yang dihasilkan belum diuji kadar dan kualitasnya. Biodiesel hasil penelitian dapat digunakan sebagai bahan bakar alternatif pengganti minyak bumi. Biodiesel ini dapat dimanfaatkan sebagai bahan bakar pada kompor biokerosin.

Metil ester asam lemak memiliki rumus molekul $\mathrm{C}_{\mathrm{n}-1} \mathrm{H}_{2(\mathrm{n}-\mathrm{r})-1} \mathrm{CO}-\mathrm{OCH}_{3}$ dengan nilai $\mathrm{n}$ adalah angka genap antara 8-24 dan nilai $r$ yaitu $0,1,2$, atau 3. Kelebihan metil ester asam lemak dibanding asam-asam lemak lainnya, antara lain ester dapat diproduksi pada suhu reaksi yang lebih rendah, dliserol yang dihasilkan dari metanolisis adalah bebas air, pemurnian metil ester lebih mudah dibanding dengan lemak lainnya karena titik didihnya lebih rendah, metil ester dapat diproses dalam peralatan karbon steel dengan biaya lebih rendah daripada asam lemak yang memerlukan peralatan stainless steel [7].

Biomassa dari mikroalga terdiri atas sejumlah komponen seperti protein dan lipid yang menyusun organella. Komposisi dari biomassa digunakan untuk karakterisasi bagaimana spesies mikroalga tersebut dapat dimanfaatkan dengan baik. Sebagai contoh, lemak mikroalga dapat dimanfaatkan sebagai biodiesel [3].

Biomassa alga terdiri atas tiga komponen utama, yaitu karbohidrat, protein dan lipid (lemak alami). Lemak utama yang terbentuk dari mikroalga adalah dalam bentuk triacylglyceride (TAG) yang dapat menghasilkan biodiesel (Danielo, 2005). Kandungan lemak dari mikroalga umumnya sekitar antara 20-50\% (berat kering), beberapa strain yang kaya lemak dapat mencapai $80 \%$ [3].

Menurut Aaronson (1980), mikroalga dapat berperan sebagai sumber senyawa kimia (organik). Alga dapat digunakan sebagai penghasil energi dalam beberapa cara. Salah satu cara yang efisien adalah penggunaan lemak alga untuk menghasilkan biodiesel. Beberapa alga dapat memproduksi gas hydrogen di bawah kondisi pertumbuhan yang khusus. Biomassa dari alga dapat dibakar seperti kayu untuk menghasilkan panas dan aliran listrik [3].

Lemak sel tunggal (LST) secara umum berasal dari tiga sumber mikroba[8], yaitu bakteri, kapang dan khamir. Sebagian besar khamir, kapang dan bakteri berpotensi untuk menghasilkan asam lemak, terutama asam lemak tidak jenuh. Kapang mempunyai kelebihan dibandingkan dengan khamir, yaitu dilihat dari kemampuan tumbuhnya pada kisaran $\mathrm{pH}$ rendah, dapat mendegradasi sumber karbon $(\mathrm{C})$ yang kompleks dan pertumbuhannya yang cepat serta dapat menghasilkan asam lemak [8].

Suhu inkubasi berpengaruh terhadap peningkatan konsumsi glukosa, sehingga berpotensi meningkatkan sintesis lemak. Suhu berpengaruh terhadap perubahan komposisi asam lemak dari LST. Asam lemak tidak jenuh relatif meningkat pada suhu yang relatif rendah

Perubahan komposisi asam lemak yang dipengaruhi oleh perubahan suhu, ada hubungannya dengan aktivitas enzim yang berperan dalam pembentukan ikatan rangkap pada komponen asam lemak yang aktivitasnya terhambat pada suhu yang tinggi, sehingga mengindikasikan bahwa pada suhu yang lebih rendah, kandungan asam lemak tidak jenuh menjadi lebih tinggi [8].

Kebanyakan kapang dapat tumbuh pada kisaran $\mathrm{pH}$ yang luas, namun biasanya pertumbuhan akan lebih baik pada kondisi asam atau $\mathrm{pH}$ rendah (Fardiaz, 1992 dalam Sumanti, 2003)[9]. Nilai pH optimum untuk pertumbuhan kapang berkisar antara 6,0-7,0, sedangkan $\mathrm{pH}$ optimum untuk produksi lemak bervariasi pada setiap spesies kapang. Namun kandungan lemak pada kapang yang ditumbuhan pada kisaran $\mathrm{pH}$ 5,5-7,5 tidaklah berbeda nyata [8]

Tabel 4. Hasil analisis asam lemak alga.

\begin{tabular}{lccc}
\hline Species Alga & \multicolumn{3}{c}{ \% Berat kering } \\
& Protein & $\begin{array}{c}\text { Karbo- } \\
\text { hidrat }\end{array}$ & Lemak \\
\hline C. vulgaris & $51-58$ & $12-17$ & $14-22$ \\
C. pyrenoidosa & 57 & 26 & 2 \\
S. dimorphus & $8-18$ & $21-52$ & $16-40$ \\
S. obliquus & $49-55$ & - & $5-10$ \\
\hline
\end{tabular}

Pengamatan yang dilakukan oleh Kessell (1996) dalam Sumanti (2003)[8] pada beberapa kapang menunjukkan bahwa kapang-kapang tersebut dapat tumbuh dan menghasilkan kandungan lemak yang sama baiknya pada $\mathrm{pH}$ 4,0-8,0. Waktu inkubasi berhubungan dengan kesempatan mikroba untuk memanfaatkan komponen nutrisi yang tersedia pada medium dan efektivitas sistem metabolisme mikroba dalam memanfaatkannya. Fase pertumbuhan mikroba terbagi dalam fase adaptasi, fase pertumbuhan awal, fase logaritmik, fase pertumbuhan lambat, fase pertumbuhan statis dan fase lag. Masa inkubasi mikroba terbaik berada pada fase stasioner dan tidak boleh melebihi fase lag [8]. Karbohidrat merupakan sumber karbon terbaik untuk pertumbuhan kapang. Sekitar 15-18\% sumber gula yang tersedia dapat dikonversi menjadi lemak. Kemampuan mengkonversi gula menjadi lemak bervariasi pada setiap kapang. Pada beberapa kapang, glukosa merupakan 
gula yang efisien untuk pembentukan lemak, sedangkan sukrosa dan fruktosa adalah pilihan berikutnya. Konsentrasi gula dalam medium akan menentukan rasio $\mathrm{C}: \mathrm{N}$ yang berpengaruh terhadap kandungan lemak yang dihasilkan [8].

Konsentrasi glukosa pada medium pertumbuhan mempengaruhi kadar miselium kering dan kadar lemak pada miselium kering. Konsentrasi glukosa yang dapat menghasilkan kadar lemak tertinggi pada miselium adalah $90 \mathrm{~g} / \mathrm{l}$ (rasio C:N 26,1). Kadar karbon yang terlampau tinggi pada medium dapat menghambat pertumbuhan karena adanya perbedaan tekanan osmotik yang dapat mengakibatkan plasmolisis dan penghambatan sintesa enzim-enzim pada rantai respirasi [8].

Rasio karbon dan nitrogen merupakan faktor penting bagi produksi LST. Rasio karbon dan nitrogen memiliki kisaran yang luas tergantung jenis kapangnya. Rasio karbon dan nitrogen yang optimum untuk pertumbuhan kapang dan produksi lemak adalah 65:1 dan 80:1[8]. Rasio karbon dan nitrogen yang lebih tinggi akan menghasilkan kandungan lemak yang lebih tinggi, tetapi pertumbuhan selnya lebih lambat, sehingga secara keseluruhan produktivitas lemaknya menjadi lebih rendah.

Esterifikasi adalah tahap konversi dari LST menjadi ester. Esterifikasi mereaksikan minyak lemak dengan alkohol. Katalis-katalis yang cocok adalah zat berkarakter asam kuat dan, karena ini, asam sulfat, asam sulfonat organik atau resin penukar kation asam kuat merupakan katalis-katalis yang biasa terpilih dalam praktek industrial[5]. Esterifikasi adalah proses yang diterapkan untuk pembuatan biodiesel dari minyak berkadar asam lemak bebas tinggi, dikonversi menjadi metil ester. Tahapan esterifikasi biasanya diikuti dengan transesterfikasi. Namun sebelum dilanjutkan ke tahapan transesterifikasi, air dan katalis yang digunakan harus disingkirkan terlebih dahulu guna memudahkan dalam prosesnya [6].

Biodiesel didefinisikan sebagai mono-alkil ester dari asam-asam lemak rantai panjang yang terkandung dalam minyak nabati atau lemak hewani untuk digunakan sebagai bahan bakar mesin diesel. Biodiesel dapat diperoleh melalui reaksi transesterikasi trigliserida dan atau reaksi esterifikasi asam lemak bebas tergantung dari kualitas minyak nabati yang digunakan sebagai bahan baku [4].

\section{KESIMPULAN}

Alga dan kapang dapat digunakan sebagai bahan alternatif pembuatan biodiesel melalui esterifikasi lemak sel tunggal (LST) pada jenis mikroba tersebut. LST pada kapang $F$. Oxysporum dan $M$. Javanicus didominasi oleh asam palmitat (41\% dan $40 \%$ ), sedangkan pada kapang A. Oryzae, M. Purpureus dan M. Sitophyla didominasi oleh asam linoleat $(42 \%, 36,1 \%$ dan $36 \%$ ). LST pada alga C. Vulgaris didominasi oleh asam linolenat (47\%), sedangkan pada alga S. Limorphus didominasi oleh asam linoleat (35 $\%)$. Asam palmitat dan linoleat berpotensi untuk menghasilkan biodiesel melalui esterifikasi.

\section{DAFTAR PUSTAKA}

1. Qazuini, M. Dan S. Satrijo. 2008. Pembuatan Biodiesel dari Minyak Jarak Pagar (Jatropha Curcas L.). Seminar Nasional Pulang Kampus Alumni Fakultas Pertanian Universitas Mataram di Mataram tanggal 23-24 Februari 2008. http://www.unraM.,ac. id/FP/PROSEDING/MAKALAH \%20PENUNJANG/ TEKNOLOGI/MakalahPenunjang7.pdf.

2. Aaronson, S. 1980. Microalgae as a source of chemicals and natural products. In: Algae biomass. Elsevier-North Holand, Biomedical Press (1980), pp. 576-601.

3. Johnson, M.B. 2009. Microalgal Biodiesel Production through a Novel Attached Culture System and Conversion Parameters. Thesis submitted to the Faculty of Virginia Polytechnic Institute and State University.

4. Joelianingsih, H. Armansyah, Tambunan. 2006. Perkembangan Proses Pembuatan Biodiesel Sebagai Bahan Bakar Nabati (BBN). Jurnal Keteknikan Pertanian. Vol. 20 No. 3 Desember 2006.

5. Soerawidjaja, T. 2006. Fondasi-Fondasi IImiah dan Keteknikan dari Teknologi Pembuatan Biodiesel. Seminar Nasional "Biodiesel Sebagai Energi Alternatif Masa Depan" UGM Yogyakarta.

6. Destianna, M., Z. Agustina, dan S.P. Nazef, 2007. Intensifikasi Proses Produksi Biodiesel. Karya IImiah Mahasiswa ITB Bidang Energi. ITB: Bandung.http:// pub.bhaktiganesha.or.id/itb77/files/Penelitian\%20 mahasiswa\%20ITB/BIODIESEL.pdf.

7. Haryanto, B. 2002. Bahan Bakar Alternatif Biodiesel. http://library.usu.ac.id / download/ft/kimia-bode.pdf.

8. Sumanti, D.M., T. Carmencita, H. Marleen dan S. Tati. 2003. Mempelajari Mekanisme Produksi Minyak Sel Tunggal dengan Sistem Fermentasi Padat pada Media Onggok-Ampas Tahu dengan Menggunakan Kapang Aspergillus terreus. http:// pustaka.unpad.ac.id/wp-content/ uploads/2009/05/ mempelajari me-kanisme_produksi_minyak_sel_ tunggal.pdf. 